\title{
Estimation of chromium reduction potential of two wetland plants using pilot scale constructed wetlands
}

\author{
B Madhumathi Devi and K V Jayakumar \\ Environmental Engineering Lab, Department of Civil Engineering, \\ National Institute of Technology, Warangal
}

\begin{abstract}
Two parallel pilot scale sub-surface flow constructed wetlands (SSFCW) are designed and fabricated. The two natural wetland plants selected for the present study are Cyperus alopecuroides and Canna indica. These plant species are grown in constructed wetland tanks A (with Canna indica) and B (with Cyperus alopecuroides) for two months by supplying fresh tap water. After the plants are grown healthy, potassium dicromate solution of different concentrations is introduced into both the tanks in a constant rate flow of 25 $\mathrm{ml} / \mathrm{min}$ in plug flow manner from inlet tanks. The hydraulic retention time (HRT) is maintained as five days. After 5 days the effluent is collected at the outlet and tested for chromium (VI). The experiment is continued for four months and chromium VI in the outlet waters is analysed. At the end of the experiment, plants are harvested and seperated into leaves, rhizomes and roots. They are seperately analysed for total chromium concentration. Bio-concentration Factor (BCF) and Translocation Factor (TF) are also estimated.
\end{abstract}

Keywords: Canna indica; chromium; Cyperus alopecuroides; heavy metals; phytoremediation; wetlands;

\author{
Abbreviations: \\ SSFCW sub-surface flow constructed wetlands \\ HRT hydraulic retention time \\ BCF bioconcentration factor \\ TF translocation factor \\ $\mathrm{CW} \quad$ constructed wetland \\ COD chemical oxygen demand \\ BOD bio-chemical oxygen demand \\ TAP trialkyl phosphate \\ ICPOES Inductively coupled plasma optical emission spectro-photometer
}

\section{Introduction}

Heavy metal pollution of soil and water is a very common feature in industrially predominant areas. Heavy metals, unlike other pollutants, are persistent in nature therefore tend to accumulate in different components of environment (Chandra et al 1997) [8]. The remediation of polluted soils and water can be successfully implemented by phytoremediation approach. Phytoremediation is a cost effective technology that can be effectively used to clean environment using plants. The metal bioaccumulation of the plants can greatly reduce the amount of heavy metal pollution of soil and water. This method is highly effective if it is carried out using hyper accumulator plants (plants which can accumulate heavy metals in high amounts). Constructed wetlands $(\mathrm{CW})$ offer a great scope for the phytoremediation of heavy metals and other toxic pollutants. The combined approach of phytoremediation using CWs has a lot advantages such as low cost of treatment, combination of higher plants, algae and bacteria, etc. The selection of plants which are specific for the pollutants is another important criterion. The detoxification mechanism involved in wetland phytoremediation differs with each class of pollutant. In the present study, the reduction of heavy metal chromium from contaminated soil is analyzed using phytoremediation method.

\section{Literature Review}

Plants belonging to family Cyperaceae are commonly known as sedges. They superficially resemble grasses and are widely distributed with the centers of diversity for the group occurring in tropical Asia and tropical South America. Many of the sedges are associated with natural wetlands. It was an age old practice to consider the members of Cyperaceae as in-situ bio-monitors and bio-remediators as they are habituated to marshy and wetland areas. Some of the species of Cyperaceae are universally available and with their ability to survive adverse conditions and high colonization rates, become excellent tools for the study of phytoremediation. They play a vital role in metal bioavailability through rhizosphere secretions and exchange processes. In view of the above unique and favourable features towards phytoremediation' the Cyperaceae family is selected for the project. 
Estimation of chromium reduction potential of two wetland plants using pilot scale constructed..

Overall et al. (2004) [1] proliferated Eleocharis dulcis in a constructed wetland to treat Uranium mine runoff water. They investigated Uranium uptake and accumulation by Eleocharis dulcis using field sampling techniques. Jinadasa et al. (2006) [2] examined the ability of Scirpus grossus planted in a constructed wetland to treat domestic wastewater. They found that Scirpus grossus has great potential to remove pollutants in constructed wetlands especially in tropical regions. Ayaz (2008) [3] studied the effectiveness of constructed wetland systems in the removal of organic matter from tertiary effluent and the potential factors effecting the removal. He grew Cyperus species in wetlands and analysed their removal capacity for various parameters like BOD, COD etc. Olmos -Marquez et al. (2012) [4] evaluated the performance of Eleocharis macrostachya for Uranium retention using constructed wetlands. His results revealed the better performance of vegetated bed to unvegetated bed, showing great difference in the percentage removal of Uranium.

Canna indica is considered to be one of the best plants for phytoremediation purpose. It is effective in the treatment of industrial waste waters through constructed wetlands. The phytoremediation of triazophos $(\mathrm{O}$, O-diethyl-O-(1-phenyl-1, 2, 4 triazole-3 base) sulphur phosphate, TAP) by canna indica in a hydrophobic system was studied by Cheng et al. (2007) [5]. The contribution of the plant to the remediation of TAP was 74\% and the plant showed potential of phytoremediation. They also found the plant as an excellent tool to be used in constructed wetlands. Subhashini et al. (2013) [6] estimated the capacity of the plant for accumulation of heavy metals and results indicated the plant as good accumulator for heavy metals. Shugeng Li et al. (2013) [7] studied the effect of Canna indica in the removal of heavy metals in sewage sludge by potted planting. They established that the role of Canna indica in heavy metal removal was significant.

\subsection{Plant selection:}

\section{Materials and Methods}

The plants selected for the present study are Cyperus alopecuroides belonging to family Cyperaceae and Canna indica belonging to family Cannaceae.

\subsubsection{Cyperus alopecuroides:}

3.1.1.1 Description of the plant: The general characteristics of these plants are that they are robust, tufted, perennial plant with fleshy roots, short, thick, woody rhizomes. Culms are generally solitary stout, trigonous in shape, leafy and thickened below. Leaves are provided with papery leaf sheaths; leaf blades are flat and folded appearing bright green above and pale green beneath. Inflorescence is umbel like, branched once are twice with digitate, cylindrical spikes. Bracts are leaf like, spikelets and ovate to oblong lanceolate and acute with numerous flowers. Fruit is ellipsoid to slightly obovoid nutlet, compressed and golden yellow to brown.

\subsubsection{Canna indica:}

3.1.2.1 Description of the plant: Canna indica is a perennial monocot, usually, growing to a height of $0.5 \mathrm{~m}$ to $2.5 \mathrm{~m}$ depending on the variety. It is a wetland plant with oblong shaped leaves and the inflorescences are long spikes. Flowers are red in colour and bisexual. Fruit is a capsule with small, black and hard seeds. As they resemble gun pellets, this plant is commonly knowns as "Indian Shot". Rhizomes of the plant are strong and thick with $3 \mathrm{~cm}$ diameter, and exhibit prolific tillering.

3.1.3 Constructed Wetland Setup: The set up consists of two acrylic tanks of dimensions (1.2mX0.5mX0.6m). Tank A is vegetated with Canna indica and tank B is vegetated with Cyperus alopecuroides as shown in Plate 1 \& 2. A gentle slope is provided to get the hydraulic gradient. Each tank is filled with a layer of $10 \mathrm{~mm}$ gravel for a depth of $7 \mathrm{cms}$, a layer of $5 \mathrm{cms}$ thick fine sand and a layer of soil of depth $30 \mathrm{cms}$. Both the tanks are provided with an inlet tank of dimensions $30 \times 60 \times 30 \mathrm{cms}$ with a control tap for water flow. The outlet zone is made of PVC pipes attached at the bottom. They are designed in such a way that the specific water level is maintained. Both the tanks are planted with young plants of Canna indica\&Cyperus alopecuroides, which are collected from nearby natural wetland. Initially the plants are allowed to have a healthy growth with normal tap water supply for a period of one month.

3.1.4 Experimentation: The constructed wetland tanks are supplied with synthetic solution of Potassium Dichromate of various concentrations starting from the month of January, 2015. Initially $5 \mathrm{mg} / \mathrm{L}$ concentrated synthetic solution is prepared from $1000 \mathrm{mg} / \mathrm{L}$ stalk by proper dilution. This is released into the wetland tanks A and B with a rate flow of $25 \mathrm{ml} / \mathrm{min}$ in plug flow manner for $8 \mathrm{hrs}$./day, the hydraulic retention time being 5 days. On the sixth day the outlet waters are collected and analyzed for chromium VI, using Lemotte smart spectro spectro-photometer. The same procedure is repeated by increasing the concentration gradually upto 50 $\mathrm{mg} / \mathrm{L}$. The experiment ran for four months and results are recorded. 
Estimation of chromium reduction potential of two wetland plants using pilot scale constructed..

3.1.5 Analysis of soil and plants:

3.1.5.1 Preparation of soil samples:The soil samples are collected from different zones of the wetland tanks before the plantation and air dried. Later they are dried in the oven at $100^{\circ} \mathrm{C}$ for 24 hours. The dried samples are ground into fine powder. $1 \mathrm{gm}$ of soil is weighed and taken in a round bottomed flask and acid digested using concentrated $\mathrm{HNo}_{3}$ for two hours. After cooling, the solution is filtered and made upto $100 \mathrm{ml}$ and analyzed for total chromium using ICPOES (Inductively coupled plasma optical emission spectro-photometer). Again at the end of the experiment, soil samples are collected from both A and B tanks and analyzed for total chromium.

3.1.5.2 Preparation of plant samples: At the end of the experiment the plants are harvested from both tanks. They are separated into roots, rhizomes and leaves; washed thoroughly and then shade dried. Later, they are cut into small pieces and dried at $100^{\circ} \mathrm{C}$ for 24 hours. Then they are ground into fine powder in a pestle and mortar. $1 \mathrm{gm}$ of each plant part is weighed, taken in a round bottomed flask and dissolved by adding $5 \mathrm{ml}$ concentrated $\mathrm{HNo}_{3}$. Now it is slow heated by open reflux method. Whenever needed concentrated $\mathrm{HNo}_{3}$ is added during heating to avoid drying. The heating is stopped when the solution is clear, allowed to cool. Later solution is filtered into a volumetric flask and made upto $100 \mathrm{ml}$ using de-ionised water. This acid digested sample is tested for total chromium using ICPOES.

3.1.6 Bioconcentration Factor:The Bioconcentration Factor (BCF) of each plant tissue can be determined using the equation :

BCF= $\frac{\text { Concentration of the element in plant tissue at harvest }(\mathrm{ppm})}{\text { Initial concentration of the element in external nutrient solution }(\mathrm{ppm})}$

3.1.7 Translocation Factor : Translocation Factor (TF) can be determined based on the formula

Concentration of the element in shoot/leaves $(\mathrm{mg} / \mathrm{kg})$

$\mathrm{TF}=$ Concentration of the element in roots $(\mathrm{mg} / \mathrm{kg})$

\section{Results and Discussion}

Table 1: Chromium Removal Efficiency of constructed wetlands A and B

\begin{tabular}{|c|c|c|c|}
\hline Sl.No & $\begin{array}{c}\text { Conc. of Cr VI in inlet } \\
\text { waters }(\mathrm{mg} / \mathrm{L})\end{array}$ & $\begin{array}{c}\text { Conc. of Cr VI at outlet } \\
\text { tank B }(\mathrm{mg} / \mathrm{L})\end{array}$ & $\begin{array}{c}\text { Conc. of Cr VI at outlet } \\
\text { tank A (mg/L) }\end{array}$ \\
\hline 1 & 05 & 0.00 & 0.00 \\
\hline 2 & 10 & 0.00 & 0.00 \\
\hline 3 & 15 & 0.01 & 0.00 \\
\hline 4 & 20 & 0.00 & 0.00 \\
\hline 5 & 25 & 0.00 & 0.00 \\
\hline 6 & 30 & 0.01 & 0.00 \\
\hline 7 & 40 & 0.00 & 0.00 \\
\hline 8 & 50 & 0.00 & 0.00 \\
\hline
\end{tabular}

4.1 The Chromium VI concentration at outlets: Table 1 clearly indicates that the outlet waters of both wetland tanks A and B do not contain any Chromium VI and most of the times it was found to be either nil or insignificant. The highest concentration of inlet waters was $50 \mathrm{mg} / \mathrm{L}$ where the plants exhibited healthy growth. At this concentration also, Chromium VI concentration in outlet waters was found to be insignificant.. This fact is an indication that the plants are resistant to Chromium VI and can be used in the field studies.

4.2 Chromium adsorption in soil: The initial chromium concentration in the wetland tanks was found to be $1.2 \mathrm{mg} / \mathrm{g}$. The concentration of total chromium at the end of the experiment was found to be $7.7 \mathrm{mg} / \mathrm{g}$ and $1.82 \mathrm{mg} / \mathrm{g}$ in the soil samples taken from Tank B and Tank A, respectively. The results are clear indication of the important role played by soil particles in heavy metal adsorption. The concentration of chromium in wetland tank B was found to be higher when compared to wetland tank A. This may be due to higher plant uptake of chromium by Canna indica of tank A than Cyperus alopecuroides of tank B.

\subsection{Chromium uptake by plants:}

4.3.1 The total Chromium concentration in roots: The highest concentration of chromium was found to be in roots in both plants, followed by leaves and then by rhizomes. The roots of Canna indica were found to be more efficient in absorption and accumulation of chromium. The amount of chromium concentration in this plant's 
Estimation of chromium reduction potential of two wetland plants using pilot scale constructed..

roots was found to be $3.4 \mathrm{mg} / \mathrm{gm}$. The chromium concentration in roots of Cyperus alopecuroides was found to be $0.84 \mathrm{mg} / \mathrm{gm}$. At the same time, the leaves of Cyperus accumulated more chromium when compared to Canna leaves and also the rhizomes. This indicates high translocation factor of Cyperus when compared to Canna.

Table 2 :Average chromium concentration in selected plant tissues (BCF=Bioconcentration Factor,

$\mathrm{TF}=$ Translocation factor)

\begin{tabular}{|l|l|l|l|l|l|l|}
\hline S No. & Plant Name & Roots $(\mathrm{mg} / \mathrm{g})$ & Rhizome $(\mathrm{mg} / \mathrm{g})$ & Leaves $(\mathrm{mg} / \mathrm{g})$ & $\mathrm{BCF}(\mathrm{mg} / \mathrm{kg})$ & $\mathrm{TF}(\mathrm{mg} / \mathrm{kg})$ \\
\hline 1. & Cyperus alopecuroides & 0.84 & 0.06 & 0.46 & 36.33 & 0.54 \\
\hline 2. & Canna indica & 3.4 & 0.04 & 0.14 & 147.05 & 0.04 \\
\hline
\end{tabular}

4.4 BCF AND TF: The BCF of Canna plant was found to be 147 and Cyperus plant was found to be 36 . The translocation factor of Cyperus plant was found to be 0.54 and that of Canna was 0.04 respectively.

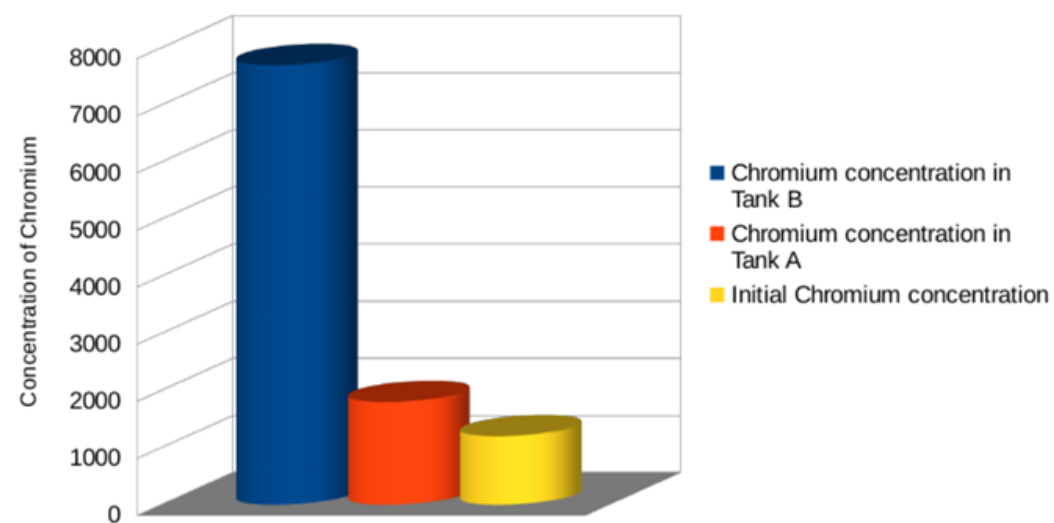

Fig 1: Comparison of Chromium concentration in soil $(\mathrm{mg} / \mathrm{Kg})$

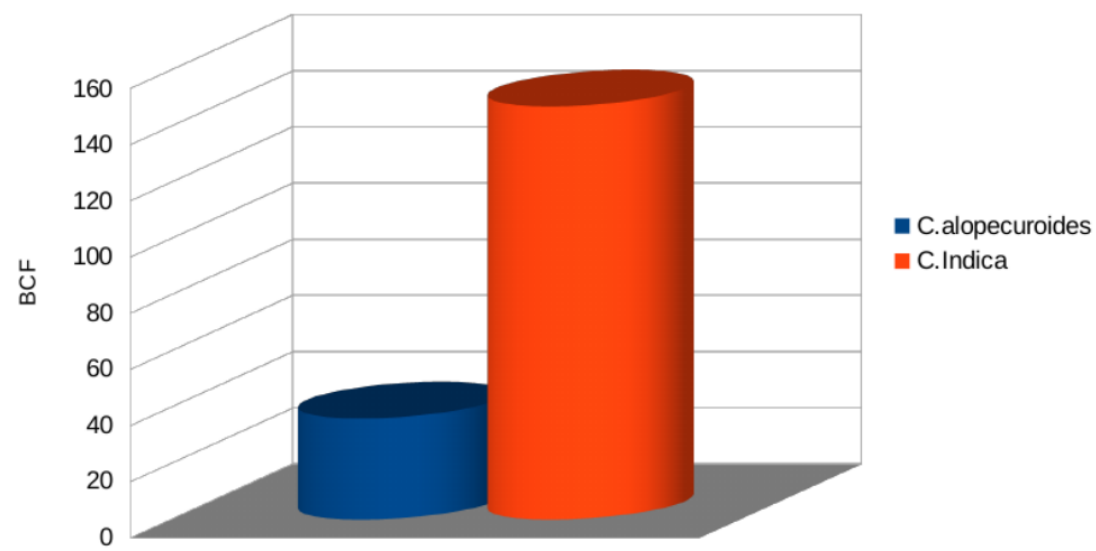

Fig 2: Comparison of Bio-concentration Factor Values

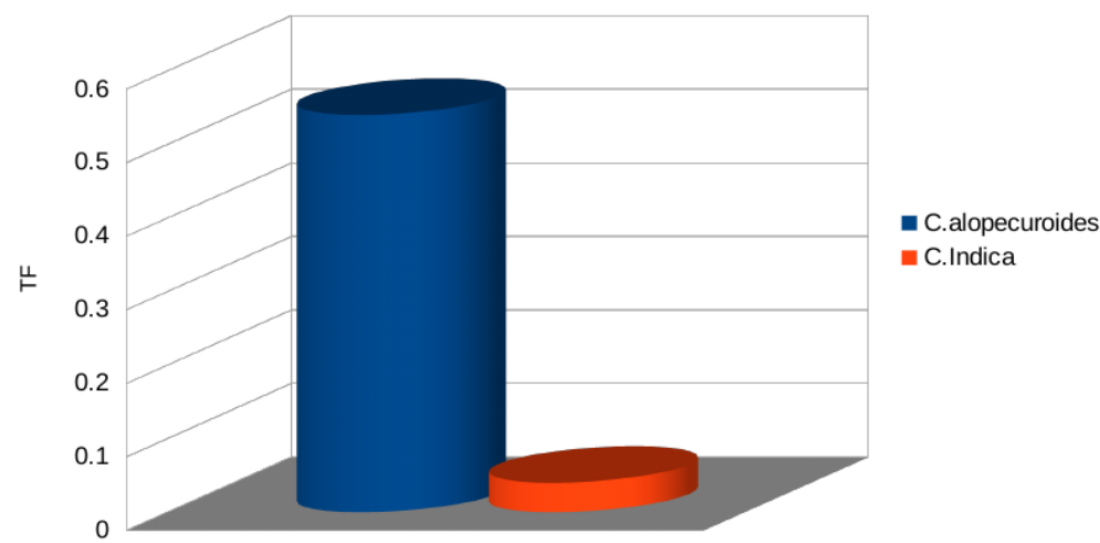


Estimation of chromium reduction potential of two wetland plants using pilot scale constructed..

Fig 3: Comparison of Translocation Factor Values

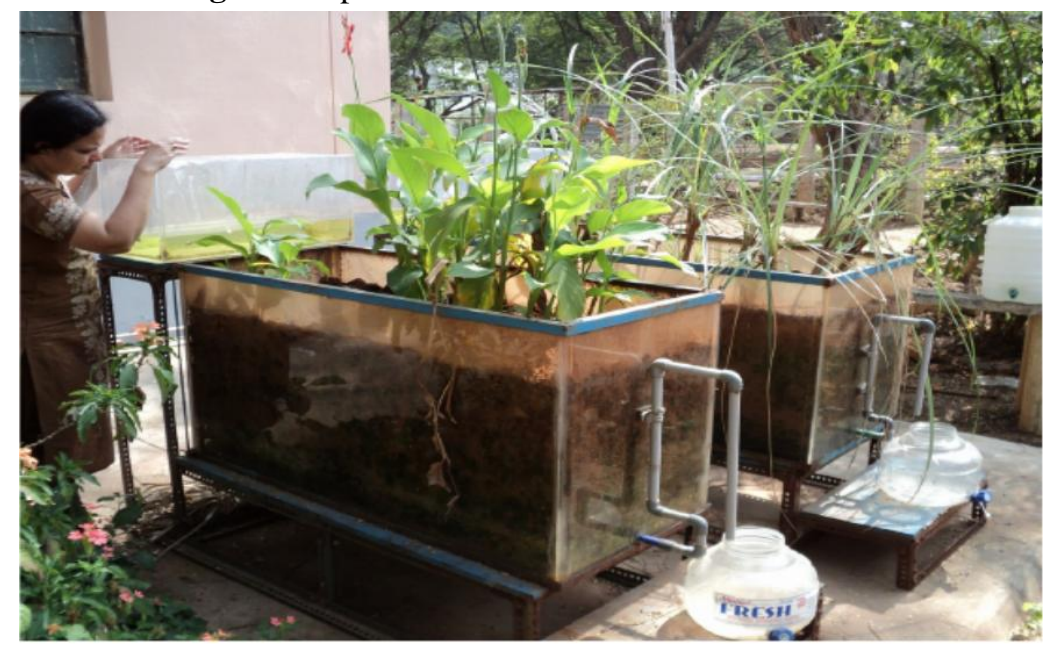

Plate: 1

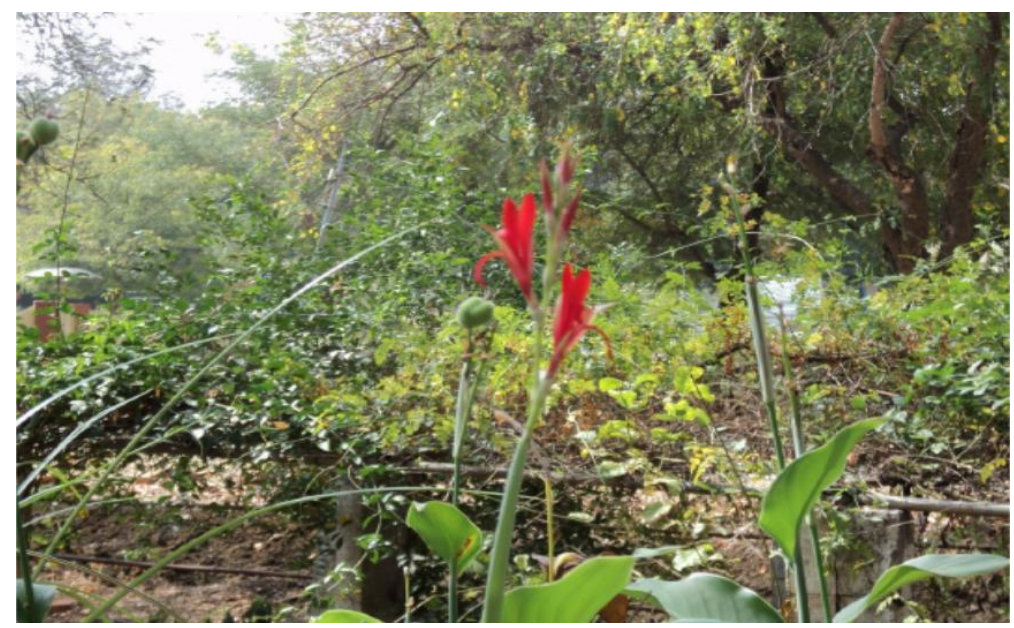

Plate: 2

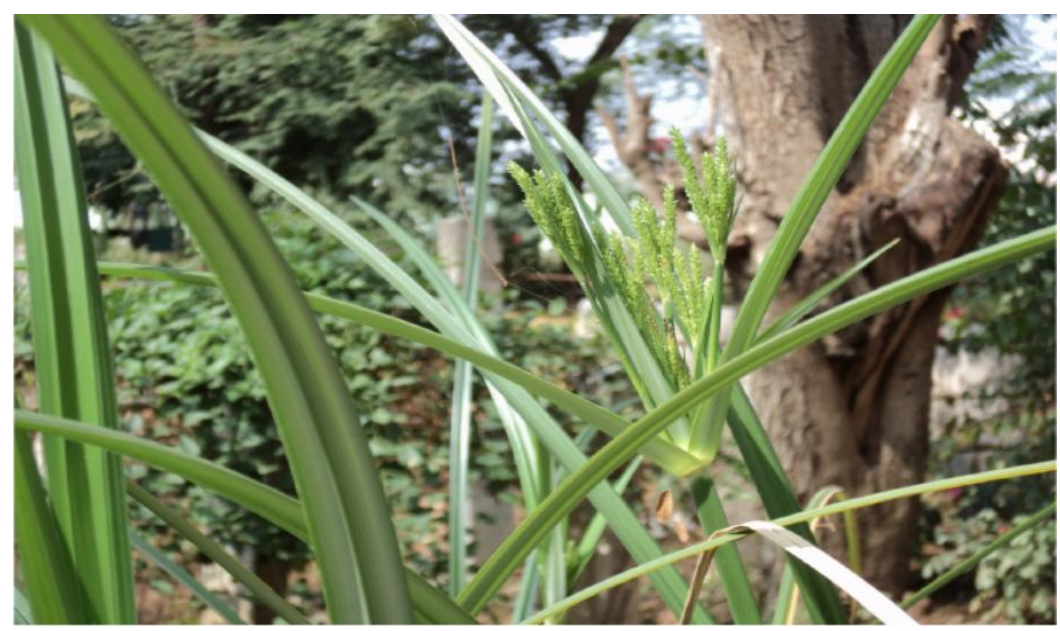

Plate: 3 


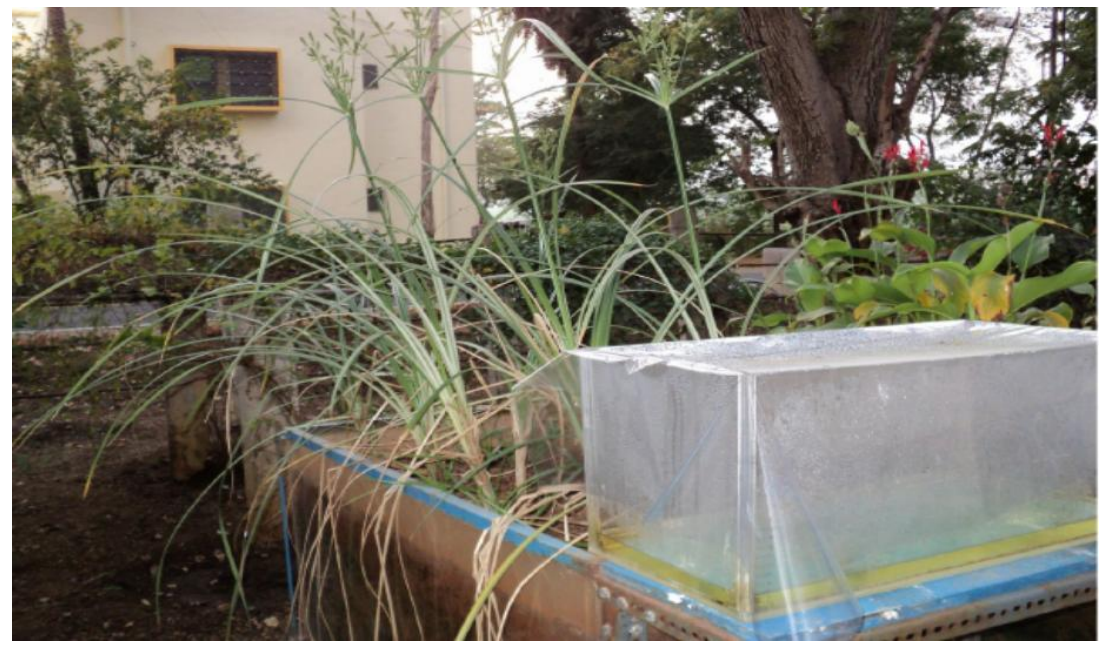

Plate: 4
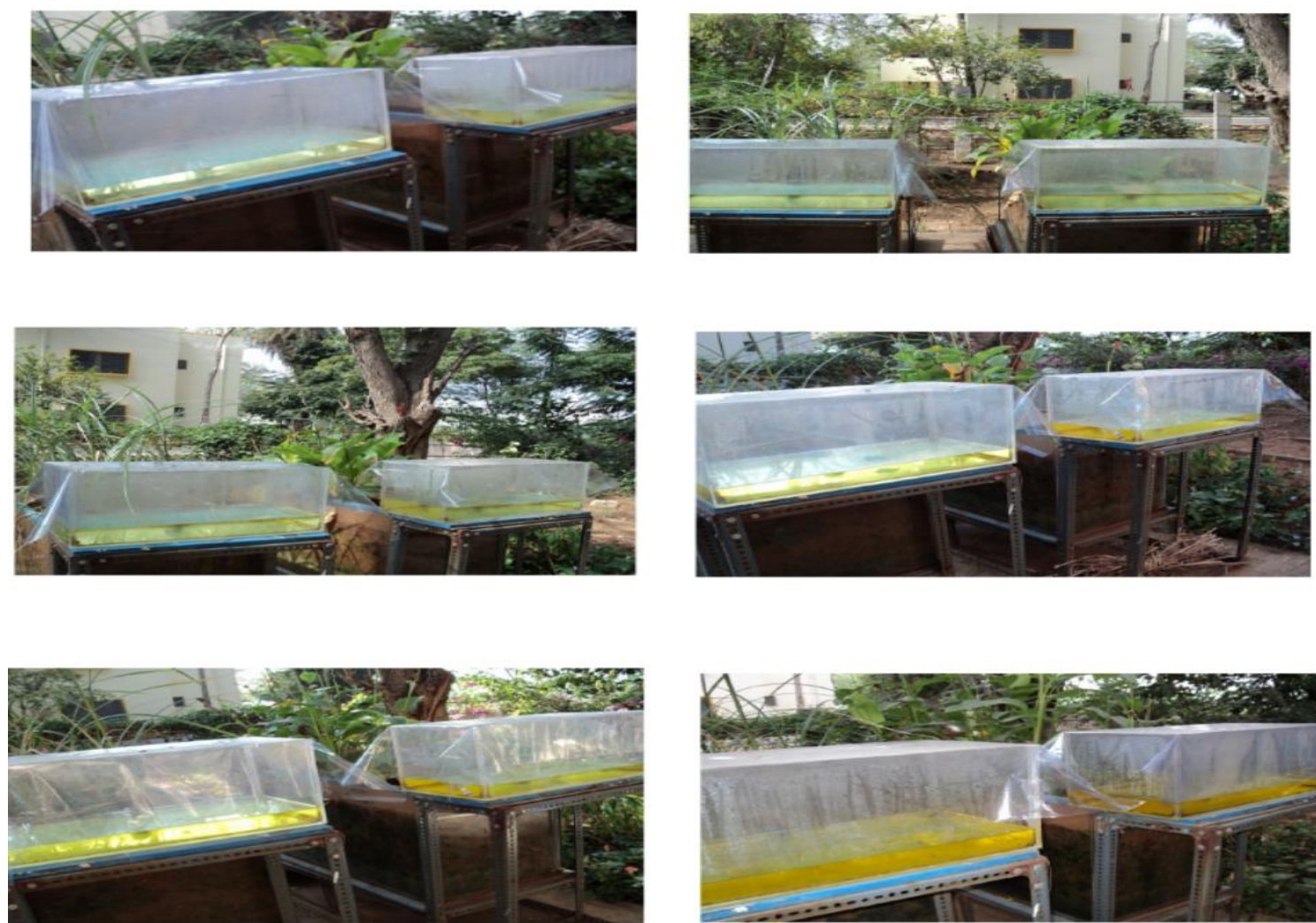

Plate: 5 Inlet tanks with Potassium Dichromate solution (Increasing Concentration)

\section{Conclusion}

The plants used for phytoremediation in the present study, Canna indica and Cyperus alopecuroides, both are found to be heavy metal accumulators. Canna accumulated more Chromium in roots and its BCF was found to be 147. But its TF was low indicating that translocation of chromium to aerial parts such as leaves were very insignificant. The chromium concentration in roots was found to be less in Cyperus when compared with Canna and the BCF value (36) is clear indication of the same. But translocation of Chromium to aerial parts is high in Cyperus, this is evident by the TF Value as shown in Table 2. Thus, it can be concluded that Cyperus is efficient accumulator as well as translocator of Chromium.

\section{Acknowledgements}


Estimation of chromium reduction potential of two wetland plants using pilot scale constructed..

Authors are thankful to the University Grants Commission, New Delhi, for the financial assistance.

\section{References}

\section{Journal Papers:}

[1] Overall, R. A. and Parry, D. L., "The uptake of uranium by Eleocharis dulcis in the Ranger Uranium Mine constructed wetland fitter", Envir, Pollute., Vol: 132(2), 2004, pp. 307-320.

[2] Jinadasa, K. B. S. N., Tanaka Norio, Mowjood, H. I. M. and Werellagama, D. R. I. B., "Effectiveness of Scirpus grossus in treatment of domestic waste in constructed wetland", Journal of fresh water ecology, Vol. 21, 2006, pp. 603.

[3] Ayaz, S. C. , "Post-treatment and reuse of tertiary treated wastewater by constructed wetlands ", Desalination, Vol: 226, 2008, pp. 249255 .

[4] Olmos-Marquez M. A., Alarcon-Herrera, M. T., and Martin-Dominquez, I.R., "Performance of Eleocharis macrostachya and its importance for arsenic retention in constructed wetlands", Environ. Sci. Pollut. Res. Int., Vol. 19 (3), 2012, pp. 763-771.

[5] Cheng S, Xiao J, Xiao H, Zhang L and Wu Z, "Technical note Phytoremediation of triazophos by Canna indica Linn. in a hydroponic system", International Journal of Phytoremediation, Nov-Dec 9(6), 2007, pp. 453-463.

[6] Subhashini, V., Ch. Ravi, D. Harika and A. Y. V. S. Swamy, "Phytoremediation of heavy metal contaminated soils using Canna indica L.", International Journal of Applied Biosciences, Vol: 1(1), 2013, pp. 09-13.

[7] Shugeng Li, Kefang Zhang, Liqin Zhang and Qintichen, "Use of ornamental in phytoremediation of heavy metals in sewage sludge", Applied Mechanics and Materials, Vol: 253-255, 2013, pp.1044-1050.

\section{Chapters in Books:}

[8] P Chandra. , S. Sinha, and U. N. Rai, Bioremediation of Chromium from Water and Soil by Vascular Aquatic Plants, Phytoremediation of Soil and Water Contaminants, Chapter 20, pp 274-282, Chapter DOI: 10.1021/bk-1997-0664.ch020, ACS Symposium Series, Vol. 664, ISBN13: 9780841235038 eISBN: 9780841216174, Publication Date (Print): April 08, 1997, Copyright @ 1997 American Chemical Society. 